RAFAŁ ROSÓŁ

Uniwersytet im. Adama Mickiewicza w Poznaniu

\title{
ŁACIŃSKIE EPITAFIA W FARZE POZNAŃSKIEJ ${ }^{1}$
}

\begin{abstract}
Rosół Rafał, Lacińskie epitafia $w$ farze poznańskiej (Latin Epitaphs in the Parish Church in Poznań).

The paper deals with three Latin epitaphs that are located in the Parish Church in Poznan (the former Jesuit Church). These inscriptions honour Stanisław Grabski (ca. 1633-1693), Kasper Drużbicki (1590-1662) and Józef Pawłowski (1698-1759). The author provides a critical edition of the inscriptions, their Polish translations, as well as a commentary.
\end{abstract}

Keywords: Latin epigraphy; Latin epitaphs; Latin inscriptions; Parish Church in Poznań; Jesuits in Poznań; Stanisław Grabski; Kasper Drużbicki; Józef Pawłowski.

W barokowym kościele pojezuickim, zwanym powszechnie farą poznańska, a oficjalnie bazyliką kolegiacką pw. Matki Bożej Nieustającej Pomocy, św. Marii Magdaleny i św. Stanisława Biskupa w Poznaniu, można doliczyć się w sumie około 200 inskrypcji łacińskich. Wśród nich znajdują się również trzy epitafia, które zdobią ściany kaplic Matki Boskiej i Świętego Krzyża, umiejscowionych po obu stronach prezbiterium.

Dwie z tych inskrypcji umieszczone są w kaplicy Matki Boskiej. Po lewej stronie kaplicy (od wschodu) wisi na ścianie tablica nagrobna z czarnego marmuru w ozdobnej ramie upamiętniająca Stanisława Grabskiego herbu Wczele (ok. 1633-1693), który został pochowany w kościele jezuickim. Grabski pełnił różne funkcje publiczne, z których najważniejsza to kasztelania w Rogoźnie, mieście położonym ok. $40 \mathrm{~km}$ na północ od Poznania. Brał on również udział w kilku wyprawach wojennych, zwłaszcza w bitwie pod Chocimiem w 1673 r., stojąc na czele chorągwi². Tablicę, nad którą znajduje się namalowany na blasze portret Grabskiego, a pod którą widnieje czteropolowa tarcza z herbami, w tym herb Wczele, ufundowała - o czym wspomniano na inskrypcji - jego

\footnotetext{
${ }^{1}$ Pragnę serdecznie podziękować dr Iwonie Błaszczyk z Biura Miejskiego Konserwatora Zabytków w Poznaniu za konsultacje w sprawie obrazu przedstawiającego ks. Kaspra Drużbickiego oraz anonimowemu recenzentowi za wnikliwą lekturę artykułu i cenne uwagi.

${ }^{2}$ O Stanisławie Grabskim vide Dworzaczek 1959-1960.
} 
druga żona, Dorota z Przysięka Grotówna³. Tablica z inskrypcją funkcjonowała pierwotnie bez ramy, do której została wstawiona wtórnie po dokonaniu prac wykończeniowych w kościele prowadzonych w pierwszej połowie XVIII wieku. Niestety umieszczenie tablicy w ramie sprawiło, że w przypadku wersów, które rozciągają się od lewej krawędzi do prawej, początkowe i końcowe litery zostały zasłonięte. Sam tekst został wyryty w majuskule, minuskule i kapitałce. Cała inskrypcja, notabene najdłuższa inskrypcja łacińska w farze i jedna z najdłuższych w Poznaniu, brzmi następująco ${ }^{4}$ :

D.(EO) O.(PTIMO) M.(AXIMO) | Subsiste hic ${ }^{5}$ non sine faventi suspirio Viator: | Legeq(ue) ${ }^{6}$ ac simul ${ }^{7}$ luge longu(m) ${ }^{8}$ ad Posteros Fun[us] | [Ill]ustrissimi D(omi)ni ${ }^{9}$ STANISLAI de Grab GRABSK[I] | CASTELlani Rogozinensis | ANTE Pocillatoris Posnan.(IENSIS) ET CAPITANEI KLECE[N.](SIS) ${ }^{10} \mid \mathrm{H}<\mathrm{U}>\mathrm{IC}^{11}$ UBI AETAS PAR ARMIS ADOLEVIT $\mid$ IN HOLSATIA, DANIA, LithVANIA, UKrainA, (ET) C(ETERA) ${ }^{12}$ CONTRA SVECOS, Hungaros, COSACOS ${ }^{13}$, TARTAROS, MOSCHO[S $]^{14} \mid$ ITA STRENU(US) ${ }^{15}$ PER ANNOS DUODEC $\{$ I $\} M^{16}$ CERTAVIT MILES $\mid$ UT DUCTOR VEXILLI SUI CONTRA TURCAS AD CHOCIMU[M $]^{17} \mid$ EMERITAM $^{18}$ CORONAVERIT $^{19}$ MILITIAM | NEC MINOR IN TOGA PATRIAE CIVIS. | COMITIOLIS ${ }^{20}$ ADFUIT PROPE OMNIBUS, PRÆFUIT NONNULlis | IUdEX DEPUTATUS PLURIES ${ }^{21}$ AD TRIBUnAl REgNi, | CUI(Us) ${ }^{22}$ ViCARIA LONGO TEM-

${ }^{3}$ Opis tego zabytku vide Kurzawa, Kusztelski 1998: 25.

${ }^{4}$ Dotychczasowe wydania: Malczewski 1747: Pars ima, 55n.; Łukaszewicz 1858: 133n.

${ }^{5}$ Malczewski (1747: Pars ima, 55) nie uwzględnia.

${ }^{6}$ Łukaszewicz (1858: 133) podaje eaeque ze znakiem zapytania; abrewiacja zaznaczona jako 3; Malczewski (1747: Pars ima, 55) odnotowuje tylko Lege.

${ }^{7}$ Brak tego wyrazu u A. Malczewskiego (1747: Pars ima, 55).

${ }^{8}$ Abrewiacja zaznaczona tyldą.

${ }^{9}$ Abrewiacja zasygnalizowana tyldą; Malczewski (1747: Pars ima, 55) pomija wyrażenie [Ill] ustrissimi D(omi)ni.

${ }^{10}$ Ante Pocillatoris Posnan.(iensis) et Capitanei Klece[n.](sis) - Malczewski (1747: Pars ima, 55) pomija cały wers (pisze jedynie \&c.).

${ }^{11}$ Błędnie zapisano formę Huic zamiast Hic; Malczewski (1747: Pars ima, 55) i Łukaszewicz (1858: 133) pozostawiają bez zmiany.

${ }^{12}$ Zapis skrócony jako \&C.; Malczewski (1747: Pars ima, 55) pomija.

${ }^{13}$ U Malczewskiego (1747: Pars ima, 55) pisownia Kosakos.

${ }^{14}$ Zamiast tego wyrazu Malczewski (1747: Pars ima, 55) podaje \&C.

${ }^{15}$ Abrewiacja zaznaczona znakiem 9.

${ }^{16} \mathrm{Na}$ inskrypcji jest DUODECEM; Malczewski (1747: Pars ima, 55) oddaje liczebnik jako 12, natomiast u Łukaszewicza (1858: 133) występuje forma poprawna gramatycznie, tj. duodecim.

${ }^{17}$ Litera $H$ zapisana w enklawie; Malczewski (1747: Pars ima, 55) umieszcza w swojej wersji Chotimum.

${ }^{18}$ Według Łukaszewicza (1858: 133) to emeritum.

${ }^{19}$ Łukaszewicz (1858: 133) odczytuje jako corona verit.

${ }^{20}$ Litera $i$ w ostatniej sylabie zapisane w enklawie $\mathrm{z} l$; Łukaszewicz (1858: 133) podaje comitiis; Malczewski (1747: Pars ima, 56) pomija cały wers.

${ }^{21}$ Index deputatus pluries - u Malczewskiego (1747: Pars ima, 56) jest: Deputatus pluries iudex.

${ }^{22}$ Lukaszewicz (1858: 134) podaje cui; Malczewski (1747: Pars ima, 56) odczytuje cujus. 
PORE DIRECTIO ${ }^{23}$ CESSIT ILLII ${ }^{24}$ IN HONOREM | COMMISSIONES $^{25}$ FISCI $^{26}$ IN MAIORI $^{27}$ POLONIA $^{28}$ PER PLURES $^{29}$ ANNOS MODERAT(US) ${ }^{30} \mid$ [IP] SE $^{31}$ APUD $^{32}$ OMNES, SEU CIVES ${ }^{33}$, SEU MILITES ${ }^{34}$, PRÆCIPU(US) ${ }^{35}$ FISCI THESAURU[S] | TANDEM TOT ${ }^{36}$ MERITORU(M) ${ }^{37}$ ET NULLO $^{38}$ VENALIS $^{39}$ SUFFRAGII PONDERE | AD SENATUM EVECTUS | INTEGRITATE, MAGNANIMITATE, DICENDI PRAESTANTIA | AMORE LEGUM BONIQ(UE) ${ }^{40}$ PUBLICI SUPERAVIT MULTOS | C[A]NDORE ${ }^{41}$, RECTITUDINE $^{42}$, ET PRO ÆQUITATE ${ }^{43}$ INCORRUPTO $^{44}$ PECTORE $^{45} \mid$ PRO FIDE ORTHODOXA ZELOSISSIMUS $^{46} \mid$ IN PAUPERES ECCLESIAS, DIVOSQUE ${ }^{47}$ ITA $^{48}$ LIBERALIS | UT ${ }^{49}$ SUPRA $40000^{50}$ IN EOS $^{51}$ EROGAVERIT $^{52}$, VIV(US)Q(UE) $)^{53}$ CELO $^{54}$ PRÆMISERIT ${ }^{55}$ PlANE, ET MERITO TERRIS ET CELO PRETIOSUS ${ }^{56}$.

${ }^{23}$ Litery $I R \mathrm{w}$ ligaturze, przy czym $R$ mniejsze, z kolei $T \mathrm{w}$ enklawie $\mathrm{w} C$.

${ }^{24}$ Drugie $L$ w enklawie.

${ }^{25}$ Litera $O$ w $C O$ zapisana w enklawie, przy czym obie litery są częściowo zasłonięte przez ramę.

${ }^{26}$ Litera $I$ w FI zapisana w enklawie.

${ }^{27}$ MA w ligaturze; u Malczewskiego (1747: Pars ima, 56) jest Majore.

${ }^{28}$ Obydwa $O$ jako enklawy.

${ }^{29}$ Litera $U$ w enklawie.

${ }^{30}$ Abrewiacja zaznaczona znakiem 9.

${ }^{31}$ Pierwsze dwie litery pod ramą; tak podaje także Malczewski (1747: Pars ima, 56), natomiast u Łukaszewicza (1858: 134) jest se.

${ }^{32} U$ zapisane w enklawie $\mathrm{w} P$.

${ }^{33}$ Pierwsze $I$ zapisane w enklawie z $C$.

${ }^{34}$ Litera $I$ w sylabie $L I$ w enklawie.

${ }^{35}$ Litery $I$ i $U$ zapisane w enklawach, natomiast abrewiacja oznaczona przez 9.

${ }^{36}$ Litera $O$ umieszczona w enklawie pod $T T$.

${ }^{37}$ Litera $O$ w enklawie, skrót zaznaczony tyldą.

${ }^{38}$ Drugie $L \mathrm{w}$ enklawie.

${ }^{39} \mathrm{NA}$ zapisane w ligaturze, natomiast $I \mathrm{w}$ enklawie.

${ }^{40}$ Abrewiacja zaznaczona jako 3.

${ }^{41} C$ częściowo zasłonięte ramą, natomiast $A$, które było zapewne w enklawie w $C$, w ogóle nie jest widoczne.

${ }^{42}$ Pierwsze $T$ i $U$ w enklawach; Malczewski (1747: Pars ima, 56) odczytuje jako Religione.

${ }^{43}$ Litery $I$ i $A$ w enklawach;

${ }^{44}$ Pierwsze $O$ i $P$ w enklawach.

${ }^{45}$ ET PRO EQUUTATE INCORRUPTO PECTORE - w wersji Malczewskiego (1747: Pars ima, 56) jest: incorrupto pro aequitate pectore.

${ }^{46}$ Łukaszewicz (1858: 134) odczytuje omyłkowo zolossimus.

${ }^{47} \mathrm{~W}$ opracowaniu Łukaszewicza (1858: 134) pojawia się divas quoque.

${ }^{48}$ Malczewski (1747: Pars ima, 56) pomija.

${ }^{49} U$ częściowo zasłonięte ramą; Malczewski (1747: Pars ima, 56) nie uwzględnia tego wyrazu.

${ }^{50}$ Malczewski (1747: Pars ima, 56) stosuje zapis XL millia; Łukaszewicz (1858: 134) podaje 4000 .

${ }^{51}$ Łukaszewicz (1858: 134) odczytuje suas; Malczewski (1747: Pars ima, 56) pomija wyrażenie ni eos.

${ }^{52}$ Drugie $E$ i $I$ w enklawach; u Malczewskiego (1747: Pars ima, 56) jest erogavit.

${ }^{53}$ Abrewiacje oznaczone znakami 9 i 3.

${ }^{54} \mathrm{E}$ i $O$ w enklawach (tak samo w następnym wersie); Malczewski (1747: Pars ima, 56) stosuje zapis ccelo (również w następnym wersie).

${ }^{55} \mathrm{U}$ Malczewskiego (1747: Pars ima, 56) widnieje forma praemisit.

${ }^{56}$ Łukaszewicz (1858: 134) stosuje pisownię praetiosus. 


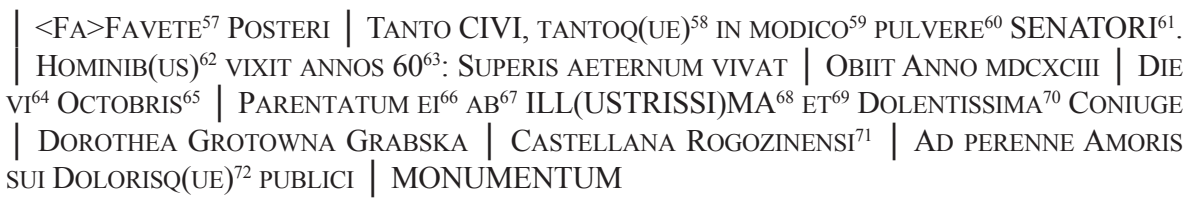

„Bogu Najlepszemu Największemu. Zatrzymaj się tutaj, przechodniu, z życzliwym westchnieniem i przeczytaj, a jednocześnie okaż smutek. To mający przetrwać długo dla potomnych pochówek Stanisława z Grabu Grabskiego, kasztelana rogozińskiego, wcześniej zaś podczaszego poznańskiego i starosty kłeckiego. On, gdy jego wiek stał się odpowiedni do noszenia broni, jako żołnierz w Holsztynie, Danii, na Litwie, Ukrainie itd. przeciwko Szwedom, Węgrom, Kozakom, Tatarom i Moskalom walczył przez dwanaście lat z takim zapałem, że uwieńczył zasłużoną służbę wojskową jako dowódca swojej chorągwi przeciw Turkom pod Chocimiem. Nie mniej wartościowym był obywatelem ojczyzny w todze. Brał udział w niemal wszystkich sejmikach, wielu z nich sam przewodził. Był wielokrotnie sędzią deputowanym do Trybunału Królewskiego, którego wiceprzewodniczenie przypadło mu w zaszczycie przez długi czas. Kierował komisjami skarbowymi w Wielkopolsce przez wiele lat. On sam u wszystkich, zarówno u obywateli, jak i żołnierzy, cieszył się opinią osoby drogocennej dla skarbu państwa. Wreszcie za sprawą zasług, a nie kupowanych głosów, został wybrany do senatu. Przewyższał wielu ludzi uczciwością, wielkodusznością, doskonałością w mowie, miłością do praw i dobra publicznego, szczerością, sprawiedliwością i nieskazitelnym sercem na rzecz równości. Był nader gorliwym obrońcą prawowiernej religii. Wobec potrzebujących kościołów i świętych ${ }^{73}$ był tak szczodry, że wydał na to ponad 40000 (złotych polskich) i za życia zapowiedział się w niebie. Z pewnością słusznie jest ceniony na ziemi i w niebie. Bądźcie życzliwi, potomni, takiemu obywatelowi i takiemu senatorowi (będącemu) w postaci odrobiny prochu! Żył dla ludzi 60 lat, dla niebian niechaj żyje wiecznie. Zmarł w roku 1693, dnia 6 października. Pomnik ten został mu wystawiony przez przesławną i pogrążoną w smutku żonę, Dorotę Grotówną Grabską, kasztelanową rogozińską, na wieczną pamiątkę jej miłości oraz powszechnego bólu”.

\footnotetext{
${ }^{57}$ Podwojona pierwsza sylaba na skutek błędu skryby.

${ }^{58}$ Abrewiacja zaznaczona jako 3 Malczewski (1747: Pars ima, 56) podaje jedynie tanto.

${ }^{59}$ Ostatnia litera w enklawie.

${ }^{60} U$ i $V$ w enklawach.

${ }^{61}$ Litera $O$ w enklawie.

${ }^{62}$ Abrewiacja zaznaczona znakiem 9.

${ }^{63}$ Malczewski (1747: Pars ima, 56) zapisuje jako $L X$.

${ }^{64}$ Lukaszewicz (1858: 134) podje słownie sexto, natomiast Malczewski (1747: Pars ima, 56) cyfrą arabską 6 .

${ }^{65}$ Malczewski (1747: Pars ima, 56) używa skrótu 8 bris.

${ }^{66} \mathrm{U}$ Malczewskiego (1747: Pars ima, 56) jest zaimek illi.

${ }^{67}$ Malczewski (1747: Pars ima, 56) notuje $a$ (cf. następne dwa przypisy).

${ }^{68}$ Abrewiacja oznaczona tyldą. Malczewski (1747: Pars ima, 56) pomija ten wyraz.

${ }^{69}$ Malczewski (1747: Pars ima, 56) nie odnotowuje.

${ }^{70} E N$ i pierwsze $I$ w enklawach, natomiast $M A$ w ligaturze.

${ }^{71}$ Malczewski (1747: Pars ima, 56) opuszcza cały wers.

${ }^{72}$ Abrewiacja oznaczona jako 3.

${ }^{73}$ Interpunkcja i postać graficzna wyrażenia IN PAUPERES ECCLESIAS, DIVOSQUE skłania do traktowania wyrazu pauperes jako przydawki do Ecclesias, niemniej nie można wykluczyć interpretacji jako: „Wobec biednych, kościołów i świętych”.
} 
Poza szczegółami z kariery politycznej i wojskowej Stanisława Grabskiego na szczególną uwagę zasługuje fakt, że inskrypcja dostarcza nam odpowiedzi na ważkie pytanie, dlaczego właściwie został on pochowany w kościele jezuickim. Chodzi tu o fragment, w którym czytamy: „Był nader gorliwym obrońcą prawowiernej religii. Wobec potrzebujących kościołów i świętych był tak szczodry, że wydał na to ponad 40000 (złotych polskich) (...)". A zatem, po pierwsze, był on

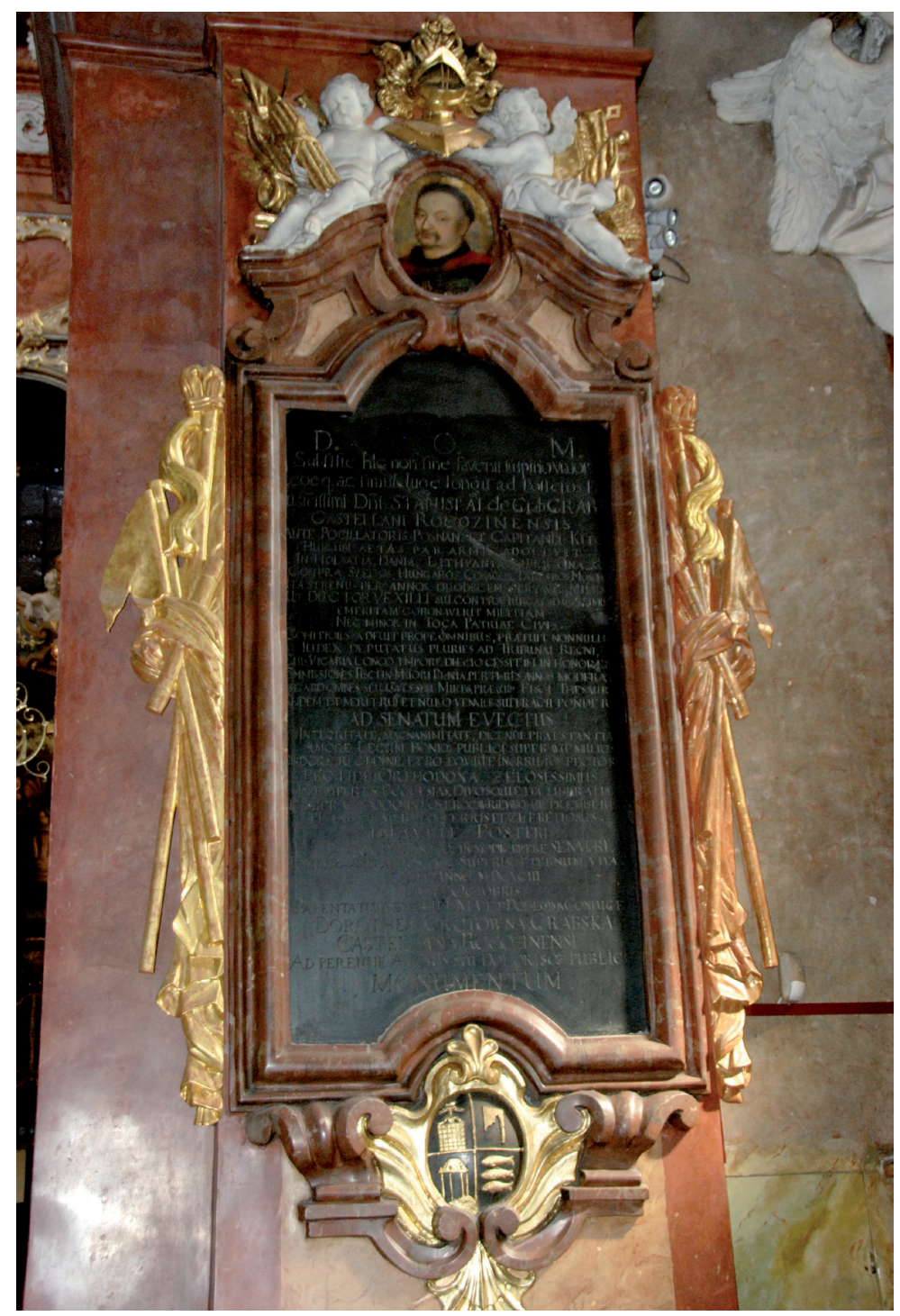

Fot. 1: Epitafium Stanisława Grabskiego ${ }^{74}$

${ }^{74}$ Autorem wszystkich fotografii jest R. Rosół. 
obrońcą katolicyzmu w trakcie trwających wówczas nadal sporów z protestantami, po drugie, łożył pieniądze na kościoły i kaplice, zwłaszcza - jak możemy się domyślać - na budowany za jego życia nowy kościół jezuitów poznańskich, których zresztą sytuacja finansowa po potopie szwedzkim była w istocie bardzo kiepska.

Drugie epitafium znajduje się po prawej stronie (od zachodu) w tej samej kaplicy. Tym razem jest to płócienny obraz o charakterze nagrobnym w ozdobnej ramie stiukowej, który przedstawia jezuitę ks. Kaspra Drużbickiego (15901662). Człowiek ten był ważną postacią w siedemnastowiecznym Kościele w Polsce, zwłaszcza jako rektor kolegiów jezuickich, prowincjał Towarzystwa Jezusowego i autor traktatów filozoficzno-teologicznych ${ }^{75}$. Na zwieńczeniu ramy znajduje się medalion $\mathrm{z}$ herbem zakonu jezuitów oraz dwa putta trzymające złoty biret. Całopostaciowy portret naturalnej wielkości datowany jest na drugą połowę XVII wieku' ${ }^{76}$.

O okolicznościach umieszczenia tego obrazu w kościele Kaziemierz Drzymała $^{77}$ pisze tak: „Kiedy zaś w r. 1698 wylew Warty zatopił grobowiec i zwłoki Drużbickiego rozsypały się, pozbierano je i umieszczono w miedzianej trumience. Zaś w kaplicy Matki Boskiej, znajdującej się nad grobowcem, umieszczono jego portret naturalnej wielkości (...)" ${ }^{\text {"78. }}$. Ta miedziana trumna z kośćmi Drużbickiego usytuowana jest nadal w podziemiach fary. Widnieją na niej inicjały $K$ i $D$, pomiędzy którymi znajduje się herb zakonu jezuitów. Jeszcze przed wojną trumna nie stała bezpośrednio na posadzce, lecz była umieszczona na murowanej podstawie $\mathrm{w}$ formie sarkofagu ${ }^{79}$.

$\mathrm{Na}$ obrazie namalowane są dwie łacińskie inskrypcje. Pierwsza z nich widnieje po lewej stronie w otwartej księdze podtrzymywanej przez ks. Drużbickiego. Litery w majuskule zostały namalowane czarną farbą na białym tle. Tekst przedstawia się tak ${ }^{80}$ :

\begin{tabular}{l|l} 
AMO & IESVM | AMORE | MARIÆ \\
AMO & MARIAM $\mid$ AMORE $\mid$ IESV $^{8}$
\end{tabular}

„Miłuję Jezusa miłością Maryi, miłuję Maryję miłością Jezusa"»2

${ }^{75}$ Vide Bednarski 1939-1946; Drzymała 1970; Grzebień 2004: 133.

${ }^{76}$ Vide Kurzawa, Kusztelski 1998: 25.

${ }^{77}$ Drzymała, 1970: 164.

${ }^{78}$ Kurzawa, Kusztelski (1998: 25) podają, że obraz pierwotnie znajdował się w zakrystii, na co jednak nie znalazłem żadnego potwierdzenia. Bez wątpienia w połowie XIX w. był on już na obecnym miejscu, co potwierdza opis Łukaszewicza (1858: 133).

${ }^{79}$ Tak podaje Zwolski (1936: 35).

${ }^{80}$ Wydania: Łukaszewicz 1858: 133; Zwolski 1936: 31; Szczepaniak 1996: 33; Chmielewski 2002: 133 .

${ }^{81}$ Łukaszewicz (1858: 133) omyłkowo podał taki tekst drugiej części: Amo Jesum amore Jesu. Z kolei Chmielewski (2002: 133) wstawia dodatkowo spójnik et pomiędzy dwie części zdania.

${ }^{82}$ Tak samo thumaczą Zwolski (1936: 31) i Szczepaniak (1996: 33). 


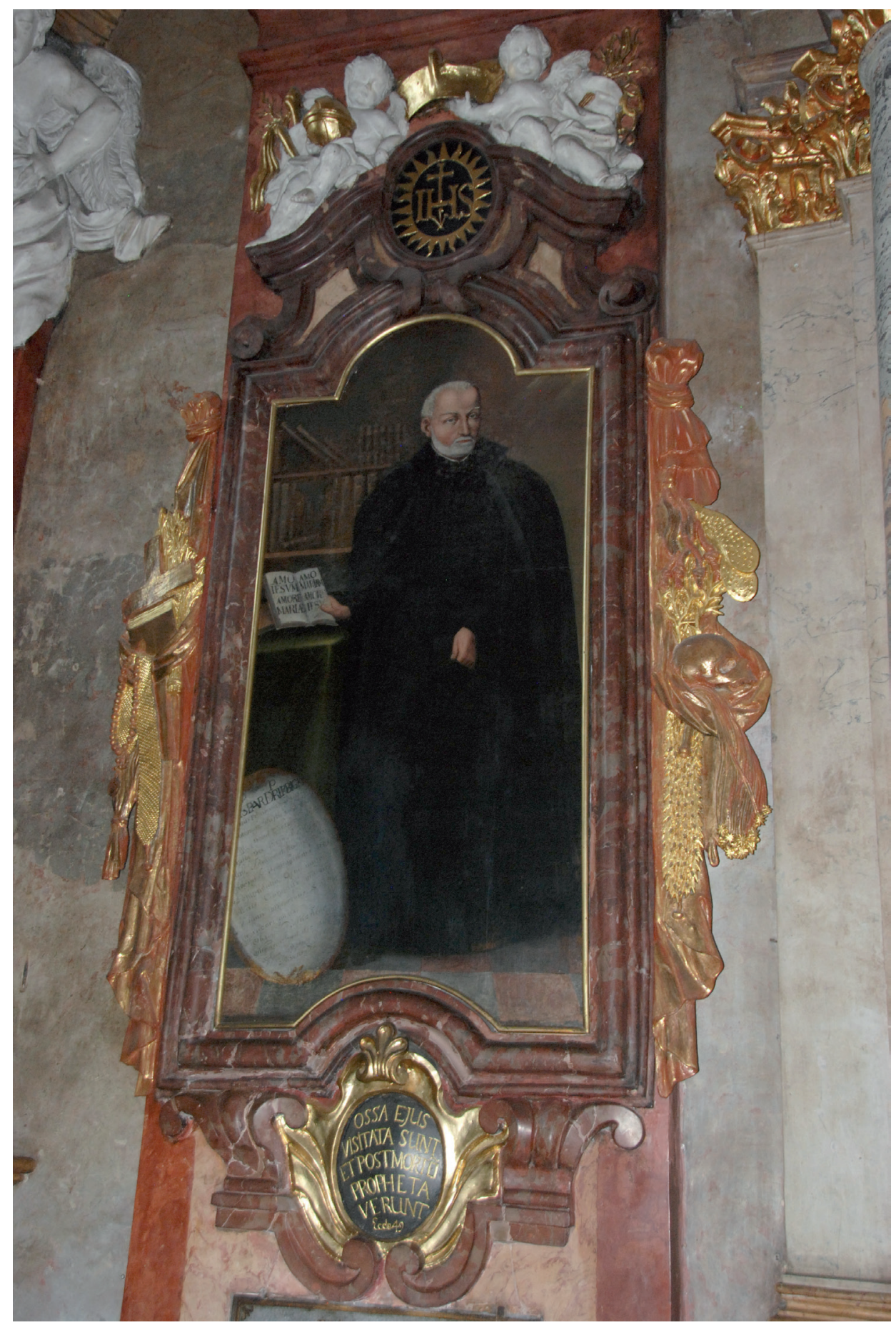

Fot. 2: Obraz przedstawiający ks. Kaspra Drużbickiego 


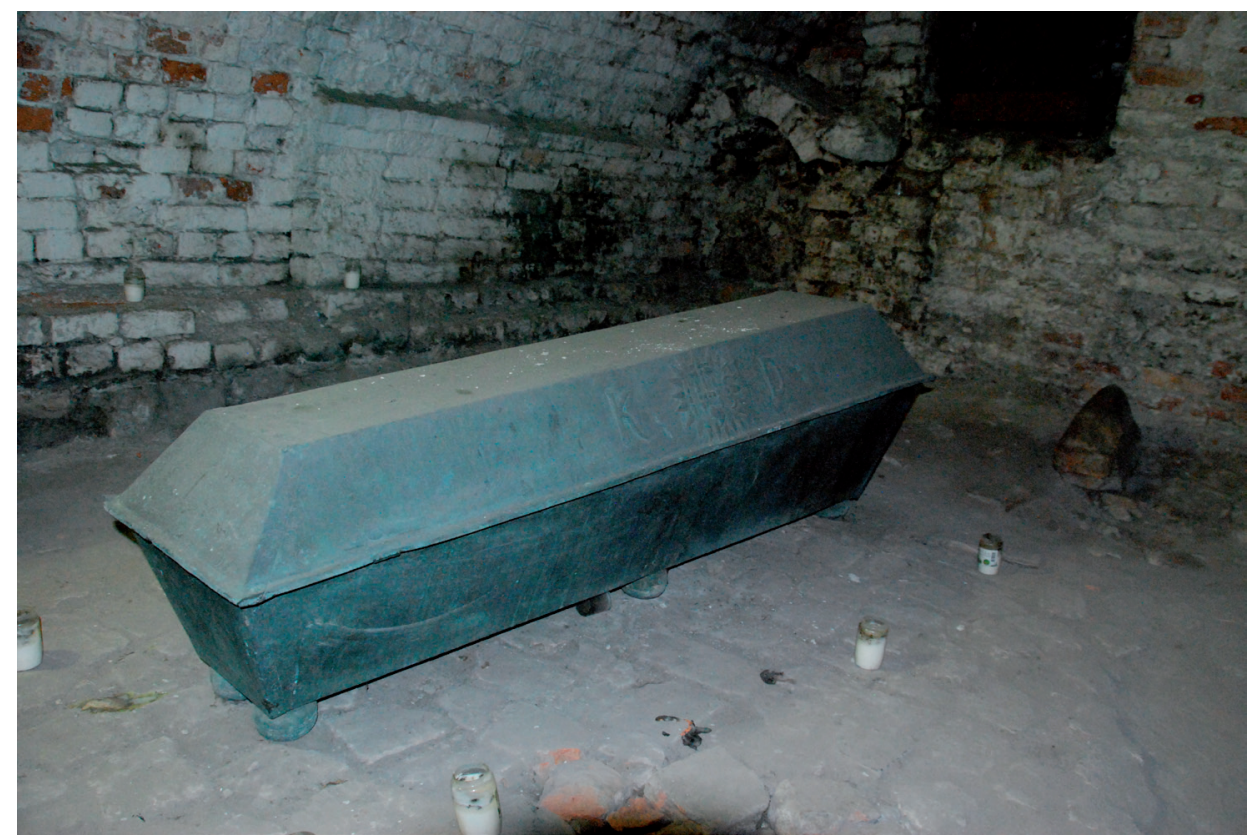

Fot. 3. Trumna ks. Kaspra Drużbickiego w podziemiach fary

Wzajemne powiązanie kultu Maryi i Chrystusa akcentowane jest w pismach teologicznych ks. Drużbickiego, czego krótką charakterystykę dostarcza Chmielewski (2002: 133): „(...) (Drużbicki) inicjując w Polsce praktykę niewolnictwa maryjnego, dał jej mocne podstawy chrystologiczne. Zwłaszcza w dziele pt. Servitium Deiparae ukazuje, jak łaska Bożego macierzyństwa dała Maryi niejako władzę nad Jej Synem, który jest Bogiem i Stwórcą. Tym samym Maryja zyskała władzę nad każdym człowiekiem i stworzeniem Bożym. W pierwszym podręczniku czcicieli Serca Jezusa pt. Meta cordium ukazuje on szczególny związek Maryi z Sercem Zbawiciela, m.in. dziełem Serca Bożego było Wniebowzięcie Maryi"83.

Druga inskrypcja, która ma już charakter ściśle epitafijny, znajduje się przy nogach ks. Drużbickiego wpisana w owalny kartusz. Na oryginalny kartusz został najpóźniej w połowie XIX w. ${ }^{84}$ namalowany nowy z inskrypcją nieco różniącą się od oryginalnej. Ta nowa wersja istniała aż do 1998 r., kiedy to w trakcie pełnej konserwacji dokonanej przez Krzysztofa Powidzkiego została usunięta ${ }^{85}$. Obecnie zatem widoczna jest pierwotna inskrypcja, niemniej jest ona bardzo

\footnotetext{
${ }^{83}$ Chrystocentryczną pobożność maryjną Drużbickiego dokładnie omawia Misiurek (1994: 240-244).

${ }^{84}$ Tę nowszą wersję podaje już Łukaszewicz (1858: 133).

${ }^{85} \mathrm{O}$ pełnej konserwacji obrazu w 1998 r. informuje karta ewidencyjna epitafium ks. Kaspra Drużbickiego w Archiwum Miejskiego Konserwatora Zabytków w Poznaniu (oprac. I. Błaszczyk, Poznań 1991. z późniejszymi uzupełnieniami).
} 


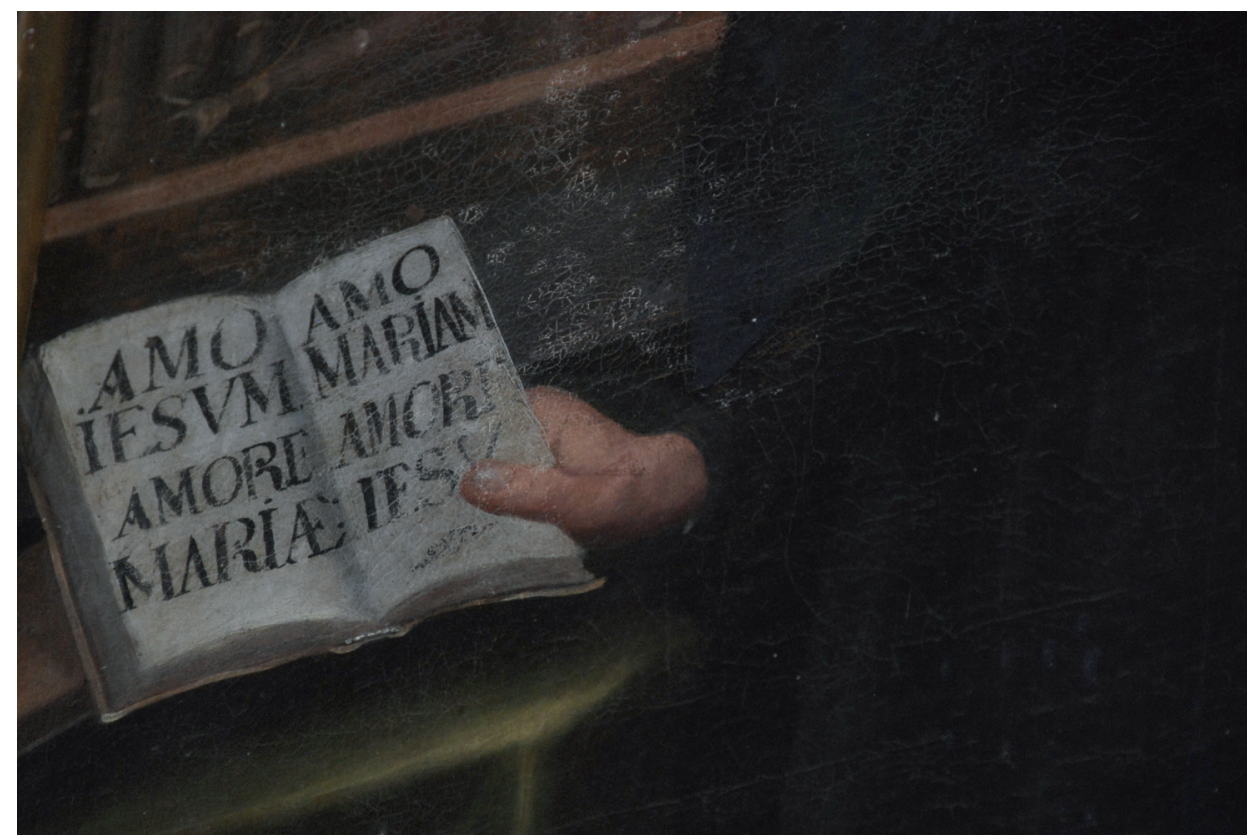

Fot. 4: Inskrypcja z obrazu przedstawiającego ks. Kaspra Drużbickiego

słabo czytelna (gdzieniegdzie występują jeszcze pozostałości liter z usuniętej wersji) i - co więcej - pewna jej część po lewej stronie znajduje się pod ramą, co zresztą zapewne było głównym powodem do namalowania kartusza jeszcze raz. Litery inskrypcji zostały sporządzone czarną farbą na białym tle w minuskule (pierwsze dwa wersy w majuskule). Tekst, który wymaga w niektórych miejscach rekonstrukcji, można odczytać następująco ${ }^{86}$ :

$\{$ R $\}$.(everendus) ${ }^{87}$ P.(ater) | [CA]SPAR DRUŻBICKI | [Praepos]itus Provincialis [Soc.(ietatis) Jesu] | [per P]oloniam. Hujus Co[1]1(egii) [Alumn(us)] | [et Rect]or ${ }^{88}$. Dono Confirmationis | [in g]ratia Dei, Propheti[ae, Miracu]|[lor]um ${ }^{89}$, Admirabili lumine in | [sc]ribendo, Pretio[s]issimaæ Dei $\mid \mathrm{P}$ [arent[is] cultu, Orbi nostro | clarus. Continuæ mortifi $\mid$ cationi immortuus (et) ${ }^{90}$ a mor $\mid$ te incorruptus. |Obii[t] Posnaniae | Mense April[i] die (secun)do ${ }^{91}$ | Anno Domini $1662 \mid$ Aetatis [72] $]^{92}$

\footnotetext{
${ }^{86}$ Brak wydań inskrypcji.

${ }^{87}$ Litera ta wygląda jak $P$.

${ }^{88}$ Hujus Co[l]l(egii) [Alumn(us)] [et Rect]or - odczyt i uzupełnienia tej części nie są całkiem

${ }^{89}$ Uzupełnienie dokonane na podstawie nowszej wersji (vide infra).

${ }^{90}$ Zapis przy pomocy znaku $\&$.

${ }^{91}$ Wyraz zapisany skrótem jako 2 do.

${ }^{92}$ Ks. Kasper Drużbicki urodził się 6 stycznia 1590 r. (vide np. Drzymała 1970: 143), a zmarł - jak podaje sama inskrypcja - 2 kwietnia 1662 r., co oznacza, że w chwili śmierci miał skończone
} pewne. 72 lata. 
„Wielebny Ojciec Kasper Drużbicki, prowincjał Towarzystwa Jezusowego na Polskę, wychowanek i rektor tego kolegium, znany naszemu światu dzięki darowi utwierdzenia w łasce Bożej, prorokowania i cudów, dzięki godnemu podziwu oświeceniu w pisaniu oraz dzięki czci dla najwspanialszej Bożej Rodzicielki. Zmarły w trakcie nieustannego umartwiania się, nienaruszony (na ciele) przez śmierć, odszedł w Poznaniu dnia drugiego kwietnia roku Pańskiego 1662 w wieku 72 lat".

Z kolei wtórna, usunięta przez konserwatora wersja inskrypcji, którą znamy z wcześniejszych odpisów i fotografii, posiada taką treśćc ${ }^{93}$ :

VENERABILIS | P.(ATER) GASPAR ${ }^{94}$ DRUŻBICKI | Societatis JESU95 | CONFIRMATIONIS IN GRATIA | DEI, | Prophetiæ, Miraculorum dono | cultu DEI-PARÆ, | Admirabili in scribendo lumine $\mid$ orbi nostro clarus, | continuæ mortificationi immortuus. $\mid 2$. April.(is) A.(nno) D.(omini) 1662 aetat.(is) $7\{2\}^{96} \mid$ Posnaniæ, | A morte incorruptum corpus | sanctissimæ animæ | probavit | integritatem.

„Czcigodny Ojciec Kasper Drużbicki z Towarzystwa Jezusowego, znany naszemu światu dzięki darowi utwierdzenia w łasce Bożej, prorokowania i cudów, dzięki czci dla Bogurodzicy oraz dzięki godnemu podziwu oświeceniu w pisaniu, umarł w trakcie nieustannego umartwiania się (dnia) drugiego kwietnia roku Pańskiego 1662 w wieku 72 lat w Poznaniu. Ciało nienaruszone przez śmierć potwierdziło nieskazitelność najświętszej duszy"97.

Jedyną poważną różnicą pomiędzy obiema wersjami jest to, że w tej starszej przywołano na początku pewne fakty biograficzne. Mowa tu najpierw o urzędzie prowincjała zakonu jezuitów w Polsce, który ks. Drużbicki piastował dwukrotnie w latach 1629-1633 i 1650-1653 (ponadto w zastępstwie w roku $1661)^{98}$. Inskrypcja informuje również o tym, że był on zarówno wychowankiem kolegium poznańskiego, jak i jego rektorem. Do kolegium uczęszczał w latach 1603-160999, a następnie w latach 1618-1622 odbył w nim studia teologiczne ${ }^{100}$, z kolei funkcję rektora pełnił w latach 1644-1647 i od roku 1657 aż do śmier$\mathrm{ci}^{101}$. W obu inskrypcjach ponadto nieco inaczej sfomułowana została informacja

${ }^{93}$ Odczytu dokonano na podstawie fotografii umieszczonej w: Kurzawa, Kusztelski 1998: fig. 378. Dotychczasowe wydania: Łukaszewicz 1858: 133; Zwolski 1936: 31.

${ }^{94}$ Zwolski (1936: 31) odczytuje jako CASPAR.

${ }^{95}$ U Zwolskiego (1936: 31) jest: e Societate Jesu.

${ }^{96}$ Łukaszewicz (1858: 133) podaje 74, natomiast Zwolski (1936: 31) - 71 i do takiego odczytu skłania fotografia, niemniej w momencie śmierci ks. Drużbicki ukończył 72 lata; vide przyp. 92.

${ }^{97} \mathrm{Cf}$. przekład Drzymały (1970: 164), który jednak odbiega znacznie od obu znanych znam wersji łacińskich: „W. O. Kasper Drużbicki, znakomity duchem apostolskim, przedziwnym światłem w pisaniu, szczytną mądrością w rządzeniu, potwierdzeniem w łasce Bożej, wysoką bogomyślnością, darem proroctwa, nabożeństwem do przenajdroższej Bogarodzicy Dziewicy, umarły z ustawicznego umartwienia, po śmierci nie skażony. Zmarł w Poznaniu 2 kwietnia 1662 r. mając lat 71”.

${ }^{98}$ Vide Bednarski 1939-1946: 403; Drzymała 1970: i52-154 i 160n.; Grzebień 2004: 133.

${ }^{99}$ Vide Drzymała 1970: 144.

${ }^{100}$ Vide Bednarski 1939-1946: 403; Drzymała 1970: 147n.

${ }^{101}$ Vide Bednarski 1939-1946: 403; Drzymała 1970: 158 i 162n.; Grzebień 2004: 133. 


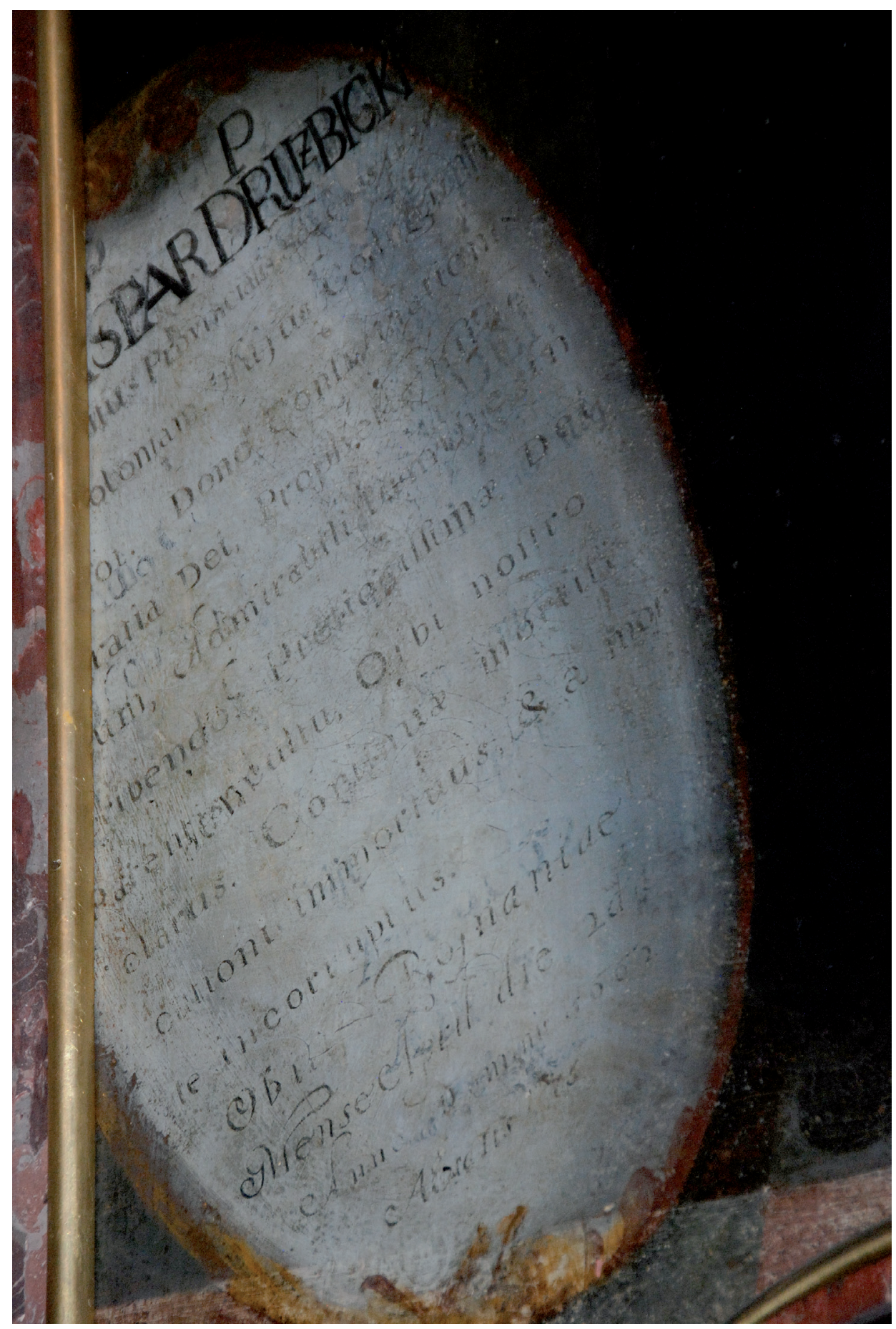

Fot. 5: Inskrypcja z obrazu przedstawiającego ks. Kaspra Drużbickiego 
dotycząca jego ciała po śmierci, które - jak powszechnie podawano - po upływie czterech lat pozostawało nienaruszone ${ }^{102}$. Reszta informacji w obu wersjach jest w zasadzie identyczna. Podkreśla się jego mistycyzm ${ }^{103}$, kult maryjny oraz ascezę praktykowaną aż do śmierci, a także działalność pisarską, na którą składają się przede wszystkim liczne traktaty ascetyczne i podręczniki do życia zakonnego ${ }^{104}$.

Pod obrazem znajduje się ozdobny kartusz wkomponowany w dolną część ramy. W kartuszu widnieje cytat biblijny zapisany literami wklęsłymi pomalowanymi złotą farbą na czarnym tle w majuskule (minuskuła tylko w jednym wyrazie) ${ }^{105}$ :

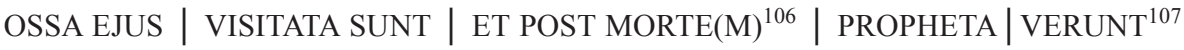 | Eccle(siasticus) ${ }^{108} 49$}

„Kości jego były oglądane i po śmierci udzieliły proroctwa”.

Cytat pochodzi z Eklezjastyka, czyli Mądrości Syracha (49.18), przy czym mamy tu do czynienia z rozszerzoną wersją znaną tylko z Wulgaty, dlatego brak w Septuagincie i w opartych na niej przekładach odpowiednika drugiej części, tj. et post mortem prophetaverunt (ponadto różni się numeracja wersów, tj. w Septuagincie 49.15 ${ }^{109}$. W tekście biblijnym zdanie to odnosi się do Józefa Egipskiego. Cytat ten odniesiono do osoby ks. Drużbickiego, ponieważ - jak informuje poprzednia inskrypcja - miał on posiadać dar prorokowania. Co istotne, wierzono, że jego ciało po śmierci posiadało moc dokonywania cudownych rzeczy, o czym Kazimierz Drzymała (1970: 163) pisze następująco: „Kiedy zwłoki jego wystawiono w kościele, całe miasto zbiegło się do jego trumny. Jedni modlili się do niego jak do świętego i otrzymywali od Boga za jego pośrednictwem różne łaski, inni ocierali o jego ciało szkaplerze, różańce i koronki, inni wreszcie zaczęli ciąć jego szaty i zabierać do domów jako cenne relikwie"110.

Trzecie epitafium w farze poznańskiej znajduje się w kaplicy Świętego Krzyża po lewej stronie (na ścianie wschodniej). Jest to obraz wraz z inskrypcją upamiętniający ks. Józefa Pawłowskiego (1698-1759). Był on prałatem

${ }^{102}$ Vide Drzymała 1970: 163.

${ }^{103} \mathrm{Na}$ temat jego utwierdzenia w łasce szczegółowo pisze Drzymała (1970: 149n.).

${ }^{104} \mathrm{O}$ działalności pisarskiej ks. Drużbickiego vide Grzebień 2004: 133.

${ }^{105}$ Brak wydań inskrypcji.

${ }^{106}$ Abrewiacja zaznaczona tyldą, przy czym pierwsza kreska pionowa litery $M$ została zapisana w ligaturze z poprzedzającym $E$.

${ }^{107}$ Przeniesienie wyrazu zaznaczone dwiema niewielkimi kreskami podobnymi do cudzysłowu.

${ }^{108}$ Nieoznaczona abrewiacja.

${ }^{109} \mathrm{Na}$ temat rozszerzonej wersji tego zdania w Wulgacie vide Kearns 2011: 59n. Cf. cały wers w przekładzie Biblii Tysiąclecia: „Nie narodził się żaden mąż taki jak Józef, zwierzchnik braci, podpora ludu, którego zwłoki doznały takiej opieki” (49.15).

${ }^{110}$ Vide także Bednarski 1939-1946: 404. 


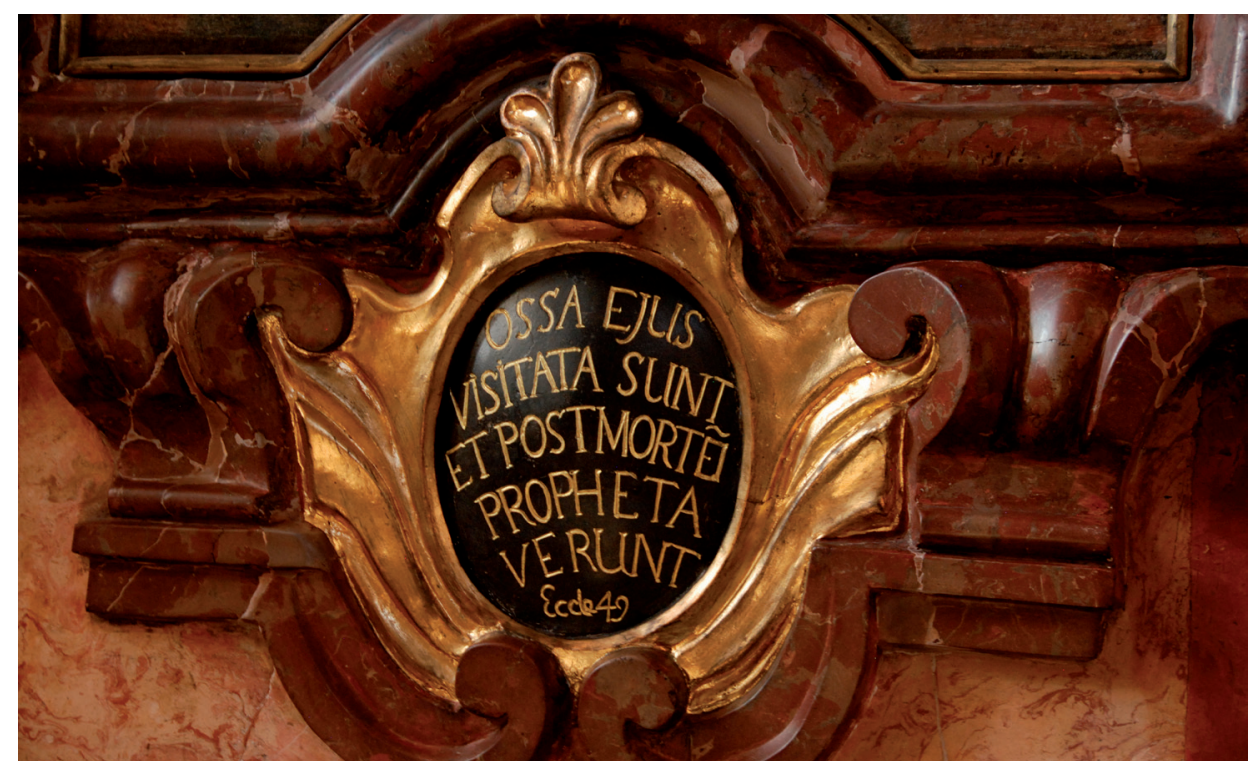

Fot. 6: Inskrypcja pod obrazem przedstawiającym ks. Kaspra Drużbickiego

prepozytem Kolegiaty św. Marii Magdaleny, gdzie po śmierci został pochowany, oraz biskupem pomocniczym diecezji poznańskiej, a ponadto pełnił inne funkcje, z których najważniejsze wymienia inskrypcja ${ }^{111}$. Obraz przedstawiający ks. Pawłowskiego pochodzi z jego czasów, niemniej został on wstawiony w ozdobną ramę i umieszczony w tej kaplicy dopiero w 1935 roku $^{112}$.

Inskrypcja, która została namalowana na desce (złotą farbą na brązowym tle w minuskule), ma charakter epitafium. Niestety zawiera ona sporo błędów, które popełnione zostały zapewne podczas prac konserwatorskich. Tekst inskrypcji wygląda tak ${ }^{113}$ :

D.(eo) O.(ptimo) M.(aximo) $\mid$ Joseph comes de $\{\mathrm{W}\} \operatorname{erb}\{\mathrm{n}\}$ o Pawlowski $\mid$ Episcop $\{\mathrm{u}\} \mathrm{s}$ $\{\mathrm{N}\}$ iochensis | Officialis Gene $\{\mathrm{r}$. $\}$ (alis) Archidiaconus Posnaniensis | Praelatus Praepositus | Collegiatae S.(anctae) Mariae Magdalenae | Praep.(ositus) Lvove\{c\}ensis | Nat.(us) 1698 $\mathrm{Ob}\{\mathrm{i}\} \mathrm{i}\{\mathrm{t}\} 1759^{114}$

„Bogu Najlepszemu Największemu. Józef, hrabia z Wierzbna Pawłowski, biskup niocheński, oficjał generalny, archidiakon poznański, prałat prepozyt Kolegiaty Świętej Marii Magdaleny, proboszcz we Lwówku, urodzony w 1698 r., zmarł w 1759 r.”

${ }^{111} \mathrm{Na}$ temat ks. Pawłowskiego vide Dymnicka-Wołoszyńska 1980.

${ }^{112}$ Vide Zwolski 1936: 24.

${ }^{113}$ Dotychczas brak wydań.

${ }^{114}$ Wspomniane błędy obserwujemy w sumie w sześciu wyrazach, tj. $\{W\} \operatorname{erb}\{n\} o$ (na inskrypcji jest: herbio), Episcop $\{u\} s$ (jest: Episcopas), \{N\}iochensis (jest: Jiochensis), Gene\{r.\} (jest: Genel bez kropki), Lvove $\{c\}$ ensis (jest: Lvoveaensis) i Ob\{i\}i\{t\} (jest: Obril). 


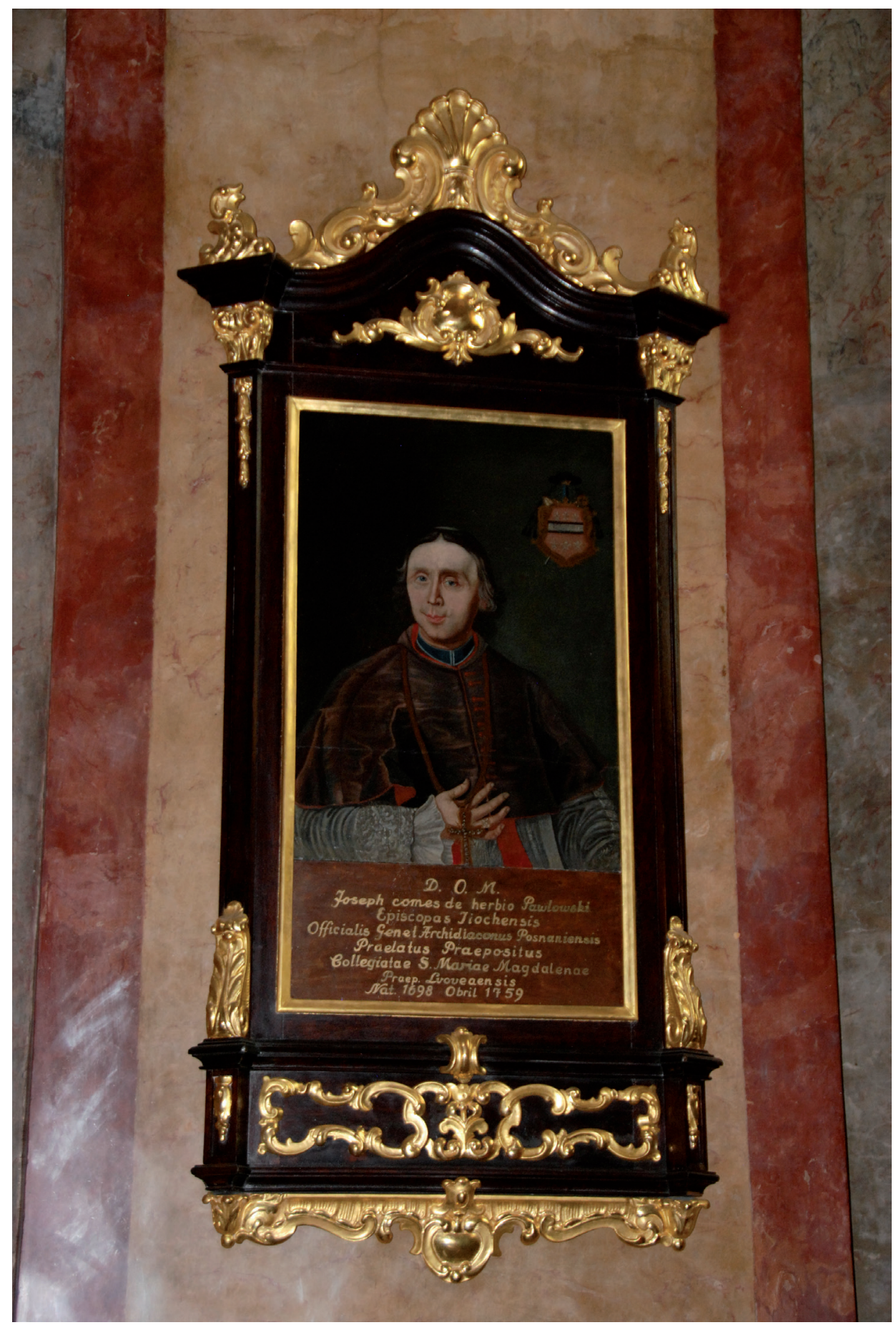

Fot. 7: Obraz przedstawiający ks. Józefa Pawłowskiego 


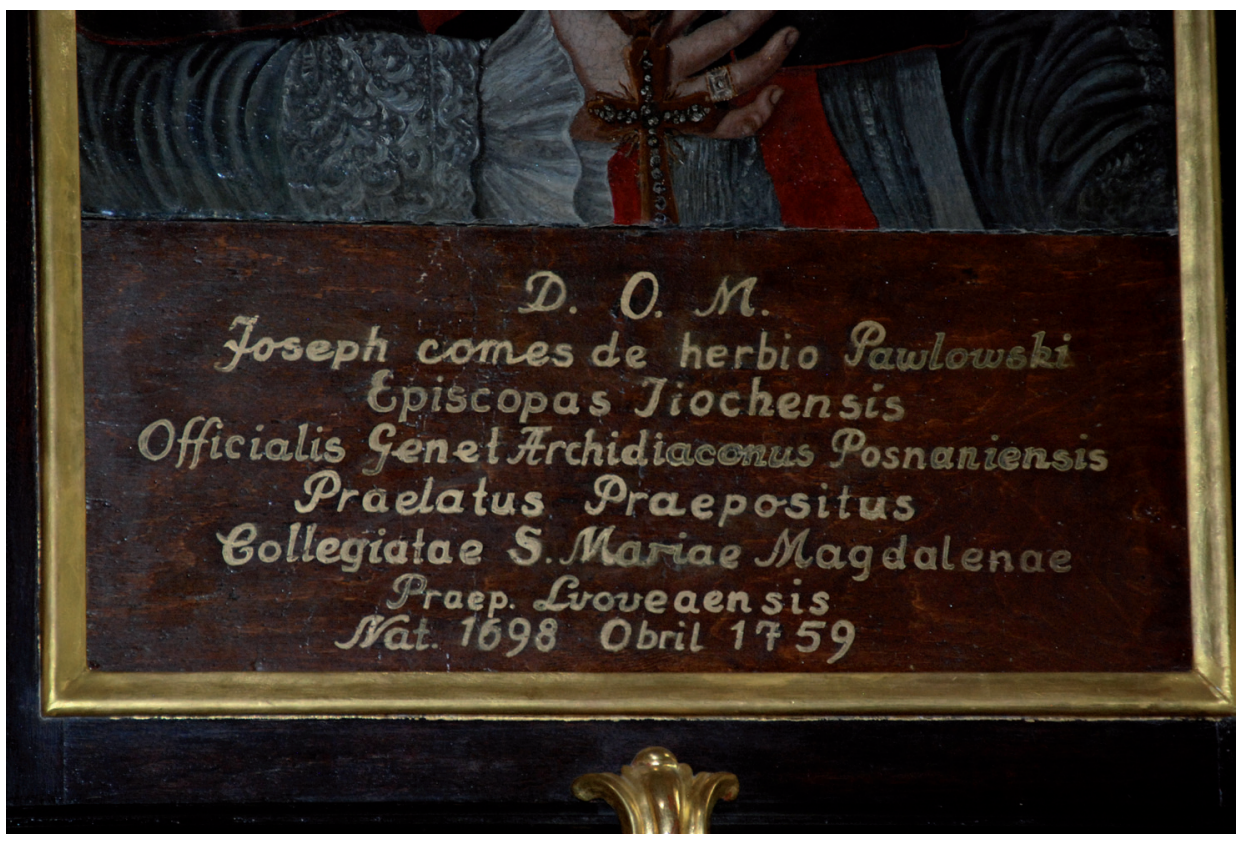

Fot. 8: Inskrypcja wkomponowana w obraz przedstawiający ks. Józefa Pawłowskiego

Spośród wymienionych funkcji najwcześniejszą jest probostwo sprawowane od 1724 r. w kościele farnym we Lwówku, który zresztą należał do posiadłości rodzinnych (właśnie we Lwówku ks. Pawłowski miał swój pałac, natomiast w tamtejszym kościele umieszczono po śmierci jego serce). W 1739 r. ks. Pawłowski został powołany na stanowisko wikariusza i oficjała generalnego diecezji poznańskiej, natomiast w 1748 r. został biskupem pomocniczym, otrzymując godność biskupa tytularnego niocheńskiego ${ }^{115}$. Z kolei prałatem prepozytem Kolegiaty św. Marii Magdaleny oraz archidiakonem poznańskim został odpowiednio w latach 1753 i $1754^{116}$.

Podsumowując, w farze poznańskiej znajdują się w sumie trzy epitafia łacińskie. Upamiętniają one ludzi, którzy zmarli w XVII i XVIII w., tj. Stanisława Grabskiego (ok. 1633-1693), ks. Kaspra Drużbickiego (1590-1662) i ks. Józefa Pawłowskiego (1698-1759). Pierwsze dwie osoby zostały pochowane w podziemiach fary, przy czym zachowała się jedynie trumna ks. Drużbickiego.

${ }^{115}$ Tytuł ten nadano mu w nawiązaniu do nieistniejącej już wówczas diecezji na wyspie Nisyros (po łacinie Dioecesis Niochensis seu Niseriensis); vide informacje zamieszczone w bazie www.catholic-hierarchy.org w hasłach Niochensis [http://www.catholic-hierarchy.org/diocese/ d2n85.html] (dostęp: 23.02.2018) i Diocese of Nisyros [http://www.catholic-hierarchy.org/diocese/dn538.html] (dostęp: 23.02.2018).

${ }^{116} \mathrm{O}$ poszczególnych funkcjach sprawowanych przez ks. Pawłowskiego vide Dymnicka-Wołoszyńska 1980. 
Z kolei ks. Pawłowski został zapewne pochowany w dawnej kolegiacie farnej pw. św. Marii Magdaleny, natomiast jego epitafium przeniesiono do nowej fary dopiero w latach 30. poprzedniego stulecia.

\section{BIBLIOGRAFIA}

Bednarski 1939-46: S. Bednarski, Drużbicki Kasper (1590-1662), w: Polski Stownik Biograficz$n y$, t. V, Kraków 1939-1946, 403n.

Chmielewski 2002: M. Chmielewski, Przez Jezusa do Maryi w duchowości polskiej, w: Przez Jezusa do Maryi. Materiały z sympozjum mariologicznego (Licheń, 26-27.10.2001), red. S.C. Napiórkowski, K. Pek, Częstochowa-Licheń 2002, 125-137.

Drzymała 1970: K. Drzymała, Ks. Kasper Drużbicki T.J., „Nasza Przeszłość” XXXIII, 143-165.

Dworzaczek 1959-60: W. Dworzaczek, Grabski Stanisław h. Wczele (ok. 1633-1693), w: Polski Słownik Biograficzny, t. VIII, Wrocław-Warszawa-Kraków-Gdańsk 1959-1960, 518n.

Dymnicka-Wołoszyńska 1980: H. Dymnicka-Wołoszyńska, Pawłowski Józef h. Wierzbno (16981759), w: Polski Stownik Biograficzny, t. XXV, Wrocław-Warszawa-Kraków-Gdańsk 1980, $504 \mathrm{n}$.

Grzebień 2004: L. Grzebień (red.), Encyklopedia wiedzy o jezuitach na ziemiach Polski i Litwy. 1564-1995, wyd. 2, Kraków 2004.

Karta ewidencyjna epitafium ks. Kaspra Drużbickiego, w: Archiwum Miejskiego Konserwatora Zabytków w Poznaniu, oprac. I. Błaszczyk, Poznań 1991 (z późniejszymi uzupełnieniami).

Kearns 2011: C. Kearns, The Expanded Text of Ecclesiasticus. Its Teaching on the Future Life as a Clue to Its Origin, Berlin-New York 2011.

Kurzawa, Kusztelski 1998: Z. Kurzawa, A. Kusztelski (red.), Katalog zabytków sztuki. Miasto Poznań, cz. II: Śródmieście. Kościoły i klasztory. 1, Warszawa 1998.

Łukaszewicz 1858: J. Łukaszewicz, Krótki opis historyczny kościołów parochialnych, kościótków, kaplic, klasztorów, szkółek parochialnych, szpitali i innych zakładów dobroczynnych $w$ dawnej dyecezyi poznańskiej, t. I, Poznań 1858.

Malczewski 1747: A. Malczewski, Umbra ligatae. Praecursio solutae eloquentiae proiecta in lucem, Poznań 1747.

Misiurek 1994: J. Misiurek, Historia i teologia polskiej duchowości katolickiej, t. I (w. X-XVII), Lublin 1994.

Pismo Święte Starego i Nowego Testamentu, w przekładzie z języków oryginalnych, opracował zespół biblistów polskich z inicjatywy Benedyktynów Tynieckich, wyd. 3, Poznań-Warszawa 1990 [tzw. Biblia Tysiąclecia].

Szczepaniak 1996: M. Szczepaniak, Fara poznańska. Przewodnik, wyd. 2, Poznań 1996.

The Hierarchy of the Catholic Church. Current and Historical Information about its Bishops and Dioceses, w: [http://www.catholic-hierarchy.org/].

Zwolski 1936: S. Zwolski, Przewodnik po farze poznańskiej, Poznań 1936.

\section{LATIN EPITAPHS IN THE PARISH CHURCH IN POZNAŃ}

Sum mary

The former Jesuit Church in Poznań (now the Parish Church) houses almost 200 Latin inscriptions of different kinds. Among them, there are three epitaphs that are located in two side chapels, namely in the Our Lady Chapel and Saint Cross Chapel. The former contains a large marble inscription devoted to the statesman Stanisław Grabski (ca. 1633-1693) of the Wczele coat of arms 
and a portrait painting (with Latin texts) of the Jesuit priest Kasper Drużbicki (1590-1662) who played an important role in the 17 th century Polish church. The latter chapel comprises an epitaph in the form of a portrait painting with an inscribed wooden board. It belongs to the priest Józef Pawłowski (1698-1759) and comes originally from the non-existing Collegiate Church of St. Mary Magdalene in Poznań. The paper provides a critical edition of the inscriptions, their Polish translations, as well as a philological and historical commentary. 